\title{
Crude aqueous extracts of Pluchea indica (L.) Less. inhibit proliferation and migration of cancer cells through induction of p53-dependent cell death
}

\author{
Jonathan J Cho ${ }^{1}$, Chung-Lung Cho ${ }^{2 *}$, Chiu-Li Kao ${ }^{2,3}$, Chien-Ming Chen ${ }^{2}$, Chao-Neng Tseng ${ }^{4}$, Ya-Zhe Lee ${ }^{2}$, \\ Li-Jen Liao ${ }^{5}$ and Yi-Ren Hong ${ }^{6}$
}

\begin{abstract}
Background: Pluchea indica (L.) Less. (Asteraceae) is a perennial shrub plant with anti-inflammatory and antioxidant medicinal properties. However, the anti-cancer properties of its aqueous extracts have not been studied. The aim of this study was to investigate the anti-proliferation, anti-migration, and pro-apoptotic properties of crude aqueous extracts of $P$. indica leaf and root on human malignant glioma cancer cells and human cervical cancer cells, and the underlying molecular mechanism.
\end{abstract}

Methods: GBM8401 human glioma cells and HeLa cervical carcinoma cells were treated with various concentrations of crude aqueous extracts of $P$. indica leaf and root and cancer cell proliferation and viability were measured by cell growth curves, trypan blue exclusions, and the tetrazolium reduction assay. Effects of the crude aqueous extracts on focus formation, migration, and apoptosis of cancer cells were studied as well. The molecular mechanism that contributed to the anti-cancer activities of crude aqueous extracts of $P$. indica root was also examined using Western blotting analysis.

Results: Crude aqueous extracts of $P$. indica leaf and root suppressed proliferation, viability, and migration of GBM8401 and HeLa cells. Treatment with crude aqueous extracts of $P$. indica leaf and root for 48 hours resulted in a significant $75 \%$ and $70 \%$ inhibition on proliferation and viability of GBM8401 and HeLa cancer cells, respectively. Crude aqueous extracts of $P$. indica root inhibited focus formation and promoted apoptosis of HeLa cells. It was found that phosphorylated-p53 and p21 were induced in GBM8401 and HeLa cells treated with crude aqueous extracts of $P$. indica root. Expression of phosphorylated-AKT was decreased in HeLa cells treated with crude aqueous extracts of $P$. indica root.

Conclusion: The in vitro anti-cancer effects of crude aqueous extracts of $P$. indica leaf and root indicate that it has sufficient potential to warrant further examination and development as a new anti-cancer agent.

Keywords: Pluchea indica (L.) Less, Crude aqueous extracts, Cancer, p53, p21, Cell growth arrest, Apoptosis

\section{Background}

Cancer is a prevalent medical problem with high mortality and wide epidemiology $[1,2]$. It is a complex disease caused by numerous factors ranging from external environmental chemicals to hereditary genetics. Current treatment of cancer can be categorized into three groups: surgery, chemotherapy, and radiation therapy [3-5]. Surgical removal of tumor and cancerous growth can effectively treat $50 \%$ of cancer but cannot eliminate

\footnotetext{
* Correspondence: clcho@faculty.nsysu.edu.tw

${ }^{2}$ Department of Biological Sciences, National Sun Yat-sen University, Kaohsiung, Taiwan

Full list of author information is available at the end of the article
}

all cancer cells, which results in high recurrence rate [4]. Chemotherapy and radiation therapy have the potential of removing all cancer cells but both lack the specificity to limit their damaging effect on cancer cells, thus harming normal body cells in the process and causing countless side-effects. Many chemotherapy chemicals target proliferating and high-metabolic cells, prominent characteristics of cancer cell and other fast-dividing cells, such as those of the integumentary system. The focal point of cancer research is still the search for effective and specific anti-cancer treatments [6].

The use of complementary and alternative therapies for cancer patients have grown in developed countries

\section{Biomed Central}


$[6,7]$. A recent study estimated the overall prevalence for the use of herbal products to be $13 \%$ to $63 \%$ among cancer patients [7]. A systematic review found that hypnosis, imagery, support groups, acupuncture, and healing touch seemed promising in relieving cancer pain in the short term; however, no formal recommendation can be made because of a paucity of rigorous randomized controlled trials [8]. In a study on the use of complementary and alternative medicine (CAM) by breast cancer survivors in Ontario, Canada, the investigators found that $66.7 \%$ of the respondents in a randomized survey reported using CAM [9]. The study concluded that CAM use is common among Canadian breast cancer survivors and that many are discussing CAM therapy options with their physicians [9]. A meta-analysis of randomized trials for combined Astragalus-based herbs and platinum-based chemotherapy, as compared to platinum-based chemotherapy alone, for advanced non-small-cell lung cancer found that Astragalus-based herbal medicine may increase effectiveness of platinum-based chemotherapy; however, rigorous controlled trials are required to confirm these results [10]. Thus, herbal medicine is emerging to play an important role in cancer treatment and survivor therapies.

Pluchea indica (Asteraceae) is a perennial shrub plant indigenous to many Asian countries [11]. Antiinflammatory properties were found in the methanolic fraction of the chloroform extract of $P$. indica root [12]. The methanolic extract of $P$. indica root was found to possess the ability to neutralize viper venom and counter venom-induced lethality and hemorrhagic activity [13]. Significant anti-ulcer and anti-tuberculosis activities were found in the methanol fraction of $P$. indica root and leaf extracts, respectively $[14,15]$.

This is the first study to demonstrate the in vitro anti-cancer property of $P$. indica aqueous extracts in the inhibition of cancer cell proliferation, focus formation, and migration. It was demonstrated that crude aqueous extracts of $P$. indica root effectively inhibited cancer cell proliferation, focus formation, and migration at low concentrations $(100-300 \mu \mathrm{g} / \mathrm{ml})$. Additionally, the underlying mechanism of anti-cancer activities may be attributed to the induction of critical tumor suppressor molecules, phosphorylated-p53 and p21, and decreased expression of an important survival signaling molecule, phosphorylated-AKT, in GBM8401 and HeLa cancer cells treated with crude aqueous extracts of $P$. indica root.

\section{Methods}

\section{Cell culture}

Human brain malignant glioma cell line GBM8401, and human cervical carcinoma cell line HeLa were used. GBM8401 was cultured in RPMI1640 (Invitrogen). HeLa was cultured in Dulbecco's modified Eagle's medium (DMEM). Both RPMI1640 and DMEM were made into complete medium with $10 \%$ cosmic calf serum (CCS; Hyclone), $200 \mathrm{mM}$ L-glutamine (Invitrogen), 1\% Penicillin (10000 units/ml)/Streptomycin (10000 units $/ \mathrm{ml})$ (Hyclone), 1X non-essential amino acids (NEAA; Invitrogen), $1 \mathrm{mM}$ sodium pyruvate (Invitrogen). Cells were incubated at $37^{\circ} \mathrm{C}$, in a humidified incubator with $5 \% \mathrm{CO}_{2}$.

\section{Preparation of Pluchea indica crude aqueous extracts}

Live plant material of $P$. indica was collected from the Yanchiao campus of National Kaohsiung Normal University, Kaohsiung, Taiwan. The plant material was authenticated and prepared as root and leaf dry powder by Professor L J Liao. The extraction of crude aqueous extracts of $P$. indica leaf or root was prepared by the method of Li et al. [16]. Briefly, $25 \mathrm{~g}$ of leaf or root powder were extracted three times in $200 \mathrm{ml}$ of $\mathrm{ddH}_{2} \mathrm{O}$ $\left(75^{\circ} \mathrm{C}-80^{\circ} \mathrm{C}\right)$ on a shaker. The resultant aqueous solution, which was filtered through $0.45-\mu \mathrm{m}$ filters, was further concentrated by quickly frozen at $-40^{\circ} \mathrm{C}$ and dried for $48 \mathrm{~h}$ using a freeze dryer (Savant Refrigerated vapor Trap, RV T41404, USA) to give a yield of $2.2 \mathrm{~g}$ crude leaf extracts (12.5\%) and $1.3 \mathrm{~g}$ of crude root extracts (9.9\%), respectively. The soluble aqueous extracts were dissolved in $\mathrm{ddH}_{2} \mathrm{O}$ to obtain stock solutions of $P$. indica leaf or root aqueous extract. Different desired concentrations of crude aqueous extracts were prepared by reconstitution with $\mathrm{dd}_{2} \mathrm{O}$ and used in this study.

\section{Preliminary phytochemical screening of Pluchea indica crude aqueous extracts}

The $P$. indica dry crude extract was evaluated for total phenol and flavonoids contents using Folin-Ciocalteu reagent and the aluminum chloride colorimetric method and was calculated as gallic acid equivalents in $\mathrm{mg} / \mathrm{g}$ of extract and catechin equivalents in $\mathrm{mg} / \mathrm{g}$ of extract, respectively, according to methods described previously with minor modifications [17]. Proanthocyanidins content was determined using the vanillin assay and expressed as catechin equivalents in $\mathrm{mg} / \mathrm{g}$ of extract as described by Butler et al. [18]. All assays were carried out in triplicate.

\section{Determination of lipid peroxidation}

Lipid peroxidation was measured in HeLa cells using the thiobarbituric acid (TBA) assay for malondialdehyde and normalized to total protein [19]. Briefly, cell pellets were mixed with $0.3 \%$ deaerated thiobarbituric acid solution in $3.9 \%(\mathrm{w} / \mathrm{v})$ trichloroacetic acid and incubated at 95$100^{\circ} \mathrm{C}$ for $20 \mathrm{~min}$. After cooling, the reaction mixtures were centrifuged at $10,000 \mathrm{rpm}$ for $10 \mathrm{~min}$. The supernatants were then loaded in 96-well plates and determined at an absorbance of $532 \mathrm{~nm} / 600 \mathrm{~nm}$. The MDA 
contents were calculated based on $\mathrm{A}_{532}-\mathrm{A}_{600}$ with the extinction coefficient of $155 \mathrm{mM}^{-1} \mathrm{~cm}^{-1}$.

\section{Cell proliferation and viability assays}

Trypan blue exclusions and the tetrazolium (3-(4,5dimethylthiazol-2-yl)-5-(3-carboxymethoxyphenyl)-2-(4sulfophenyl)-2H-tetrazolium; MTS) reduction assay were used to monitor the proliferation and viability of cancer cells upon exposure to different concentrations of aqueous extracts for different incubation periods. For the MTS assay, CellTiter 96 Aqueous One Solution Cell Proliferation Assay Kit (Promega, USA) was used by following manufacturer's protocol. Briefly, $2 \times 10^{3}$ cells/ well was seeded in 96-well plates. Following a 24-hour incubation, $P$. indica leaf or root aqueous extract at 0 , 100,500 , and $1000 \mu \mathrm{g} / \mathrm{ml}$ concentrations was added and incubated for 72 hours. After the 72-hour incubation, the medium was removed, $100 \mu \mathrm{l}$ of medium with $20 \mu \mathrm{l}$ of MTS solution was added, and the cells were incubated for 3 hours. Absorbance was read at $490 \mathrm{~nm}$ with an ELISA Reader (Micro Quant, BIO-TEK, USA) and analyzed using the KC4 $3.3 \mathrm{Rev} 10$ program (BIO-TEK instruments Inc., USA). Trypan blue dye exclusion was used to assess the viability of cancer cells grown under different conditions as described above. Growth curves, each covering a total of 6 days of culturing, were constructed from which the effects of $P$. indica aqueous extract on population doubling time and saturation density were determined.

\section{Focus formation assay}

One hundred cells were seeded in $60-\mathrm{mm}$ plates and incubated at $37^{\circ} \mathrm{C}, 5 \% \mathrm{CO}_{2}$ for 24 hours. The plates were prepared in triplicates. Following a 24-hour incubation, various concentrations of $P$. indica root aqueous extract were added. After 10 days, colonies were stained with crystal violet and counted.

\section{In vitro "scratch" wound closure assay}

In vitro wound closure assay was performed as described previously [20]. In brief, HeLa cells with 90\% confluence were wounded by scraping across the cell monolayer with a pipette tip. After washing with PBS, cells were incubated in the media supplemented with aqueous extracts of $P$. indica root at 0,250 , and $500 \mu \mathrm{g} / \mathrm{ml}$ concentrations, respectively. "Scratch" wound closure of the scratched surface was observed and photographed at 0-, 24-, 48-, and 72-hour time intervals.

\section{Apoptosis assay and flow cytometry analysis}

Determination of apoptosis was conducted following manufacturer's protocol by staining with FITC Annexin V Apoptosis Detection Kit I (BD Pharmingen, BD Biosciences, USA). Briefly, cells were plated in 100-mm culture dishes and allowed to grow to $70-80 \%$ confluence. They were treated with appropriate concentrations of aqueous extract and incubated for 2 days. The cells $\left(1 \times 10^{5}\right.$ cells/ $100 \mu \mathrm{l}$ were collected and $5 \mu \mathrm{l}$ of FITC Annexin V and $5 \mu \mathrm{l}$ of propidium iodide (PI) were added. Cells were then incubated in the dark at room temperature. After $15 \mathrm{~min}, 400 \mu \mathrm{l}$ of $1 \times$ binding buffer was added to the cells. Flow cytometry analysis was conducted using BD LSR II Flow Cytometer (BD). Flow cytometry data were analyzed using BD FACSDiva software (BD).

\section{Western blot analysis}

After treatment with $P$. indica aqueous extracts, cells were lysed with T-PER protein extraction reagent (Pierce), and $20 \mu \mathrm{g}$ protein was used for immunoblotting analysis. Immunoblotting proteins were eluted by boiling for $5 \mathrm{~min}$ in a $1 \times$ SDS sample buffer containing $5 \%(\mathrm{v} / \mathrm{v})$ 2-mercaptoethanol. Proteins were resolved in a $12 \%$ SDS-PAGE and transferred to nitrocellulose membranes. The nitrocellulose membranes were immunoblotted with specific antibodies against p21 (Santa Cruz Biotechnology), phosphorylated-p53 (pS15) (Cell Signaling Technology), AKT (Cell Signaling Technology), phosphorylated-AKT (Cell Signaling Technology), Cleaved Caspase-3 (Asp175) (5A1E) Rabbit mAb (Cell Signaling Technology), $\alpha$-tubulin (NeoMarkers), or $\beta$-actin (SIGMA), respectively. For visualization of immunoreactive bands, ECL + reagents (Amersham) followed by chemiluminescence were used. Control and experimental groups were generated from the same blot.

\section{Statistical analysis}

Data are presented as mean \pm standard deviations (SD) of three independent experiments and statistical significance was determined using Independent Student's $t$-test and the SPSS 12.0 software (SPSS Inc., USA). A significant difference was considered if $P<0.05$.

\section{Results}

\section{Phytochemical screening}

The preliminary phytochemical analysis performed on crude aqueous extracts of $P$. indica leaf and root revealed the presence of tannins, saponins, flavonoids and proanthocyanidins. The total phenol content of the crude aqueous extract of $P$. indica root was $78.9 \mathrm{mg}$ gallic acid equivalent/g of dry extract with reference to standard curve $\left(\mathrm{y}=3.5547 \mathrm{x}-0.0159, \mathrm{R}^{2}=0.9997\right)$ (Table 1). The total flavonoids and proanthocyanidins contents of the plant were $40.4 \mathrm{mg}$ and $4.248 \mathrm{mg}$ catechin equivalent/g of dry extract with reference to standard curves $\left(\mathrm{y}=0.0038 \mathrm{x}-0.0075, \mathrm{R}^{2}=0.9997\right.$ and $\left.y=0.0118 x+0.0347, R^{2}=0.9924\right)$, respectively (Table 1). The screened phytochemical compounds are known to support bioactive activities in medicinal plants and thus 
Table 1 Phytochemical compounds of Pluchea indica root aqueous extract.

\begin{tabular}{lccc}
\hline $\begin{array}{l}\text { Phytochemical } \\
\text { compounds }\end{array}$ & $\begin{array}{c}\text { Amount } \\
\text { present }\end{array}$ & Mean $^{\mathbf{N}} \pm$ SD & $\begin{array}{c}\text { Percentage in } \\
\text { extract }\end{array}$ \\
\hline Flavonoids & ++ & $\mathrm{ND}$ & $\mathrm{ND}$ \\
Tannins & ++ & $\mathrm{ND}$ & $\mathrm{ND}$ \\
Saponins & + & $\mathrm{ND}$ & $\mathrm{ND}$ \\
Total phenol & +++ & $78.9 \pm 0.6 \mathrm{mg} \mathrm{GAE} / \mathrm{g} \mathrm{DW}$ & 7.89 \\
Total flavonoids & ++ & $40.4 \pm 0.3 \mathrm{mg} \mathrm{CE} / \mathrm{g} \mathrm{DW}$ & 4.04 \\
Proanthocyanidins & + & $4.248 \pm 0.068 \mathrm{mg} \mathrm{CE} / \mathrm{g}$ & 0.42 \\
& & $\mathrm{DW}$ & \\
\hline
\end{tabular}

$\mathrm{N}=3 ;+++=$ appreciable amount (positive within $3 \mathrm{~min}$.) $+++=$ moderate amount (positive after $3 \mathrm{~min}$., but within $5 \mathrm{~min}$.) $++=$ trace amount (positive after $5 \mathrm{~min}$.); $\mathrm{GAE}=$ gallic acid equivalents; $\mathrm{CE}=$ catechin equivalents.

responsible for the anti-proliferation and anti-migration activities of the crude aqueous extracts of $P$. indica used in this study.

\section{Membrane lipid oxidation}

The levels of lipid peroxidation (thiobarbituric acid reactive species; TBARS) was indirectly measured by monitoring the production of MDA equivalents from the oxidation of malondialdehyde in HeLa cells treated with $0.5 \mathrm{mg} / \mathrm{ml}$ of crude aqueous extracts of $P$. indica root after 24-hr and 48-hr incubation (Figure 1). A significant increase in MDA equivalents, which corresponds to an increase of lipid peroxide on membranes, was observed for cells incubated for 48-hr with crude aqueous extract. The pro-oxidant activity of the crude aqueous extracts of $P$. indica root in HeLa cancer cells was evident (Figure 1).

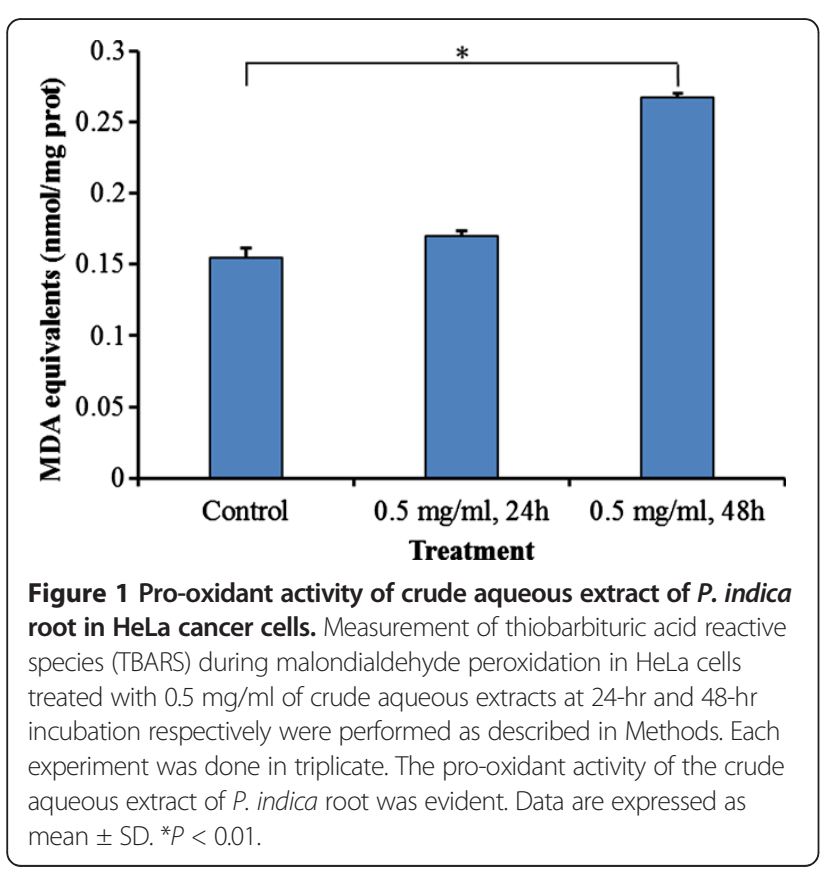

Crude aqueous extracts of $P$. indica leaf and root suppress cancer cell growth

High rate of proliferation is a hallmark of cancer cells. To examine the effect of $P$. indica leaf and root aqueous extracts on cancer cell proliferation, growth curve experiments were performed. The inhibitory effect of the extract treatment was time-dependent (Figure 2). It was observed that $300 \mu \mathrm{g} / \mathrm{ml}$ of $P$. indica leaf and root aqueous extracts suppressed GBM8401 brain cancer cell growth at day 6 as compared to untreated cells $(P<0.05)$ (Figure 2A). At both day 4 and day 6, the same dosage $(300 \mu \mathrm{g} / \mathrm{ml})$ of $P$. indica leaf and root aqueous extracts inhibited HeLa cervical cancer cell growth as compared to untreated cells $(P<0.05)$ (Figure $2 \mathrm{~B})$.

\section{Crude aqueous extracts of $P$. indica leaf and root decrease proliferation and viability of cancer cells}

To further determine the effect of $P$. indica leaf or root aqueous extracts on cancer cell proliferation and viability, MTS assay was performed. The effect of inhibition by these extracts was dose-dependent on both types of cancer cells (Figure 3 ). At the $1 \mathrm{mg} / \mathrm{ml}$ dose, both leaf and root extracts were effective, and treatment with $1 \mathrm{mg} / \mathrm{ml}$ for 72 hours resulted in $75 \%$ inhibition on GBM8401 brain cancer cells (Figure 3A). As shown in Figure 2B, treatment with leaf or root extract at the $1 \mathrm{mg} / \mathrm{ml}$ dose also resulted in significant inhibition $(70 \%)$ of proliferation and viability of HeLa cells. The results indicated that $P$. indica aqueous extracts exerted anti-proliferation activity on GBM8401 and HeLa cancer cells.

\section{Crude aqueous extracts of $P$. indica root inhibits cancer cell focus formation}

Focus formation assay was performed to examine the inhibitory effect of $P$. indica root aqueous extract on proliferation of cancer cells. Ten days after incubation in $10 \mu \mathrm{g} / \mathrm{ml}$ and $100 \mu \mathrm{g} / \mathrm{ml} P$. indica root aqueous extracts, GBM8401 cells showed diminished focus formation, and HeLa cells showed marked decrease in focus formation after $100 \mu \mathrm{g} / \mathrm{ml} P$. indica root aqueous extract treatment compared to untreated cells in both cell lines (Figure 4). When treated with $200 \mu \mathrm{g} / \mathrm{ml} \mathrm{P.} \mathrm{indica} \mathrm{root}$ aqueous extract, both GBM8401 and HeLa cells showed nearly zero focus formation when compared to untreated cells (Figure 4D,H).

\section{Crude aqueous extracts of $P$. indica leaf and root represses cancer cell migration}

Many cancer cells exhibit migratory properties, and migration is essential for cancer cells during metastasis. In vitro "scratch" wound closure assay was performed to further examine the inhibitory effect of $P$. indica leaf or root aqueous extracts on the migratory activity of cancer cells. When treated with $250 \mu \mathrm{g} / \mathrm{ml}$ or $500 \mu \mathrm{g} / \mathrm{ml}$ leaf or 

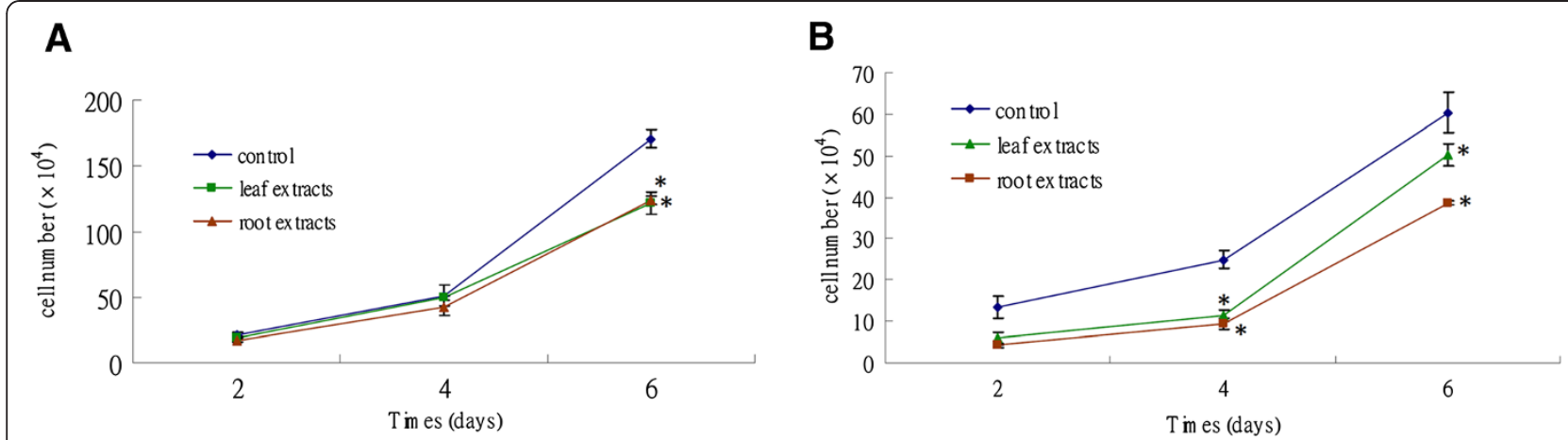

Figure 2 Effect of $\boldsymbol{P}$. indica leaf or root crude aqueous extract on the growth of cancer cells. Growth curves of (A) GBM8401 cells and (B) HeLa cells after $300 \mu \mathrm{g} / \mathrm{ml}$ P. indica leaf or root aqueous extract treatment. Each experiment was done in triplicate. Data are expressed as mean $\pm \mathrm{SD}$. ${ }^{*} P<0.05$.

root aqueous extracts and $250 \mu \mathrm{g} / \mathrm{ml}$ root aqueous extract, less migratory GBM8401 cells were found in the gap after 72 hours of extract incubation (data not shown). For HeLa cells, compared to control, less than $50 \%$ and $25 \%$ migrating cells can be found in the gap after 48 hours incubation with $250 \mu \mathrm{g} / \mathrm{ml}$ and $500 \mu \mathrm{g} / \mathrm{ml}$ $P$. indica root aqueous extract, respectively (Figure $5 B, C$, $\mathrm{D}, \mathrm{E})$. Thus, $P$. indica leaf and root aqueous extract, at concentrations of $250 \mu \mathrm{g} / \mathrm{ml}$ and $500 \mu \mathrm{g} / \mathrm{ml}$, showed highly repressive effect on migration of HeLa cells.

\section{$P$. indica root aqueous extracts induce apoptosis in HeLa cervical carcinoma cells}

The induction of apoptosis in cancer cells is another characteristic of anti-cancer agents. FITC-annexin V and propidium iodide (PI) staining assay was performed to examine the pro-apoptotic potential of $P$. indica root aqueous extract in HeLa cells. Fluorescence microscopy analysis (Figure 6) demonstrated that significant apoptosis occurred in HeLa cells treated with crude aqueous root extracts of $P$. indica for 48 hours as depicted by stronger staining of the cells by the Annexin V antibody (green; Figure 6E) as compared to the control cells (Figure 6B). PI staining (red; Figure $6 \mathrm{~F}$ ) was also noted, indicating late apoptotic or necrotic cells. To measure the percentage distribution of $P$. indica extract-induced apoptotic and necrotic HeLa cancer cells, flow cytometry was performed (Figure 7A and Figure 7B). In control HeLa cells, there was only $0.1 \%$ of apoptotic cells (Figure 7A; Quadrant 4-1). After 48 hours of treatment with $0.5 \mathrm{mg} / \mathrm{ml} P$. indica root aqueous extract, approximately $43 \%$ of HeLa cells were detected as undergoing the end stage of necrosis and apoptosis (Figure 7B; Quadrant 2-1+Quadrant 4-1). In addition, activation of caspase-3, which is marked by cleavage of procaspase-3, is shown by Western blotting (Figure 7C), which corroborated with results obtained with fluorescence microscopy (Figure 6) and flow cytometry (Figure $7 \mathrm{~A}$ and Figure $7 \mathrm{~B}$ ) analysis; caspase 3 is
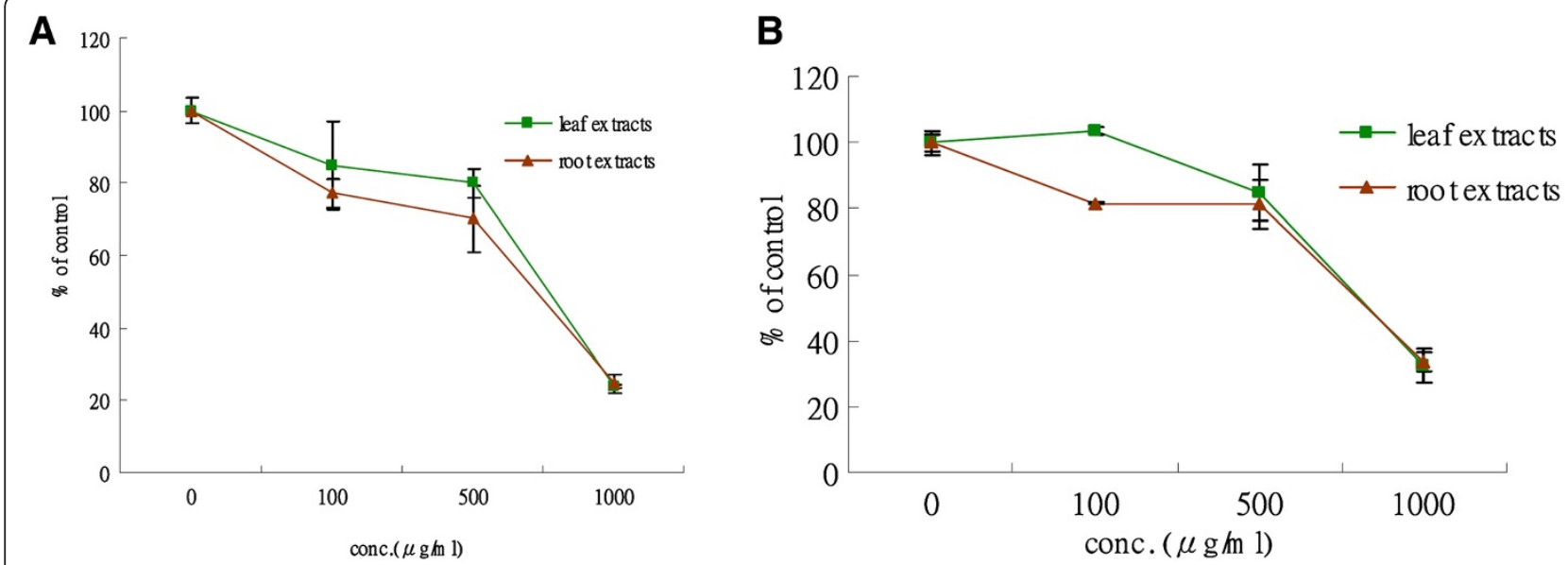

Figure 3 Effect of $P$. indica leaf or root crude aqueous extract on cell proliferation and viability of cancer cells as determined by MTS assay. MTS assay of (A) GBM8401 cells and (B) HeLa cells after 0, 100, 500, and $1000 \mu \mathrm{g} / \mathrm{ml} P$. indica leaf or root aqueous extract treatment. Each experiment was done in triplicate. Data are expressed as mean \pm SD. 

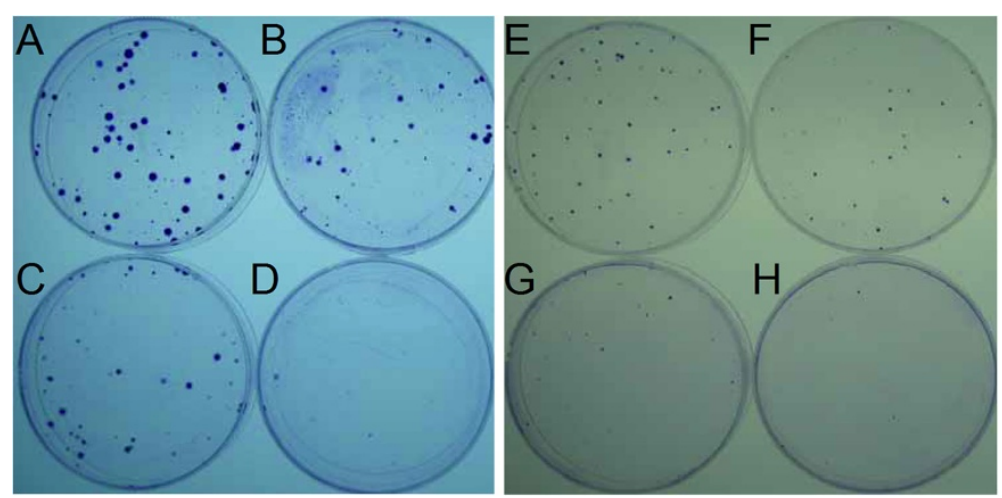

Figure 4 Effect of $P$. indica root crude aqueous extract on the focus formation ability of cancer cells. Focus formation assay of (A, B, C, D) GBM8401 cells and $(\mathbf{E}, \mathbf{F}, \mathbf{G}, \mathbf{H})$ HeLa cells after $P$. indica root aqueous extract treatment. $(\mathbf{A}, \mathbf{E}) 0 \mu \mathrm{g} / \mathrm{ml} P$. indica root aqueous extract treatment. (B, F) $10 \mu \mathrm{g} / \mathrm{ml} P$. indica root aqueous extract treatment. (C, G) $100 \mu \mathrm{g} / \mathrm{ml} P$. indica root aqueous extract treatment. (D, H) $200 \mu \mathrm{g} / \mathrm{ml} P$. indica root aqueous extract treatment. Each experiment was repeated five times.

one of the key executioners of apoptosis. Thus, $P$. indica root aqueous extract at $0.5 \mathrm{mg} / \mathrm{ml}$ concentration effectively induced apoptosis/necrosis in HeLa cells.

\section{$P$. indica root aqueous extracts suppress cancer cell proliferation and migration through the phosphorylated- p53 and p21 pathways}

To elucidate the underlying mechanism in the inhibition of cancer cell proliferation and migration by $P$. indica leaf or root aqueous extracts, Western blots of phosphorylatedp53 and p21 were examined. Phosphorylated-p53 and p21 were found to be induced in GBM8401 cells treated for 3 days with $1 \mathrm{mg} / \mathrm{ml} P$. indica leaf (lane 6) and root (lane 3) aqueous extracts (Figure 8A). Phosphorylated-p53 and p21 were found to be induced and phosphorylated-AKT were found to be decreased in HeLa cells treated for 48 hours with $0.25 \mathrm{mg} / \mathrm{ml}$ and $0.5 \mathrm{mg} / \mathrm{ml} P$. indica root aqueous extracts (Figure 8B).

\section{Discussion}

This study examined the cell growth arrest, anti-proliferation, anti-migration, and pro-apoptosis properties of Pluchea indica leaf and root crude aqueous extracts in human brain malignant glioma cell line GBM8401, and human cervical carcinoma cell line HeLa. The underlying inhibitory mechanism of $P$. indica leaf and root crude aqueous extract was also investigated. It was detected that membrane lipid oxidation level in HeLa cells increased after treatment with $P$. indica crude aqueous extract. The data showed that $P$. indica leaf and root crude aqueous extracts were effective in suppressing the proliferation and migration of GBM8401 and HeLa cells. It was found that $P$. indica root crude aqueous extract inhibited focus formation of GBM8401 and HeLa cells, and promoted apoptosis in HeLa cells. The data indicated that phosphorylated-p53 and p21 were induced in $P$. indica root crude aqueous extract-treated GBM8401 and HeLa cells, and that phosphorylated-
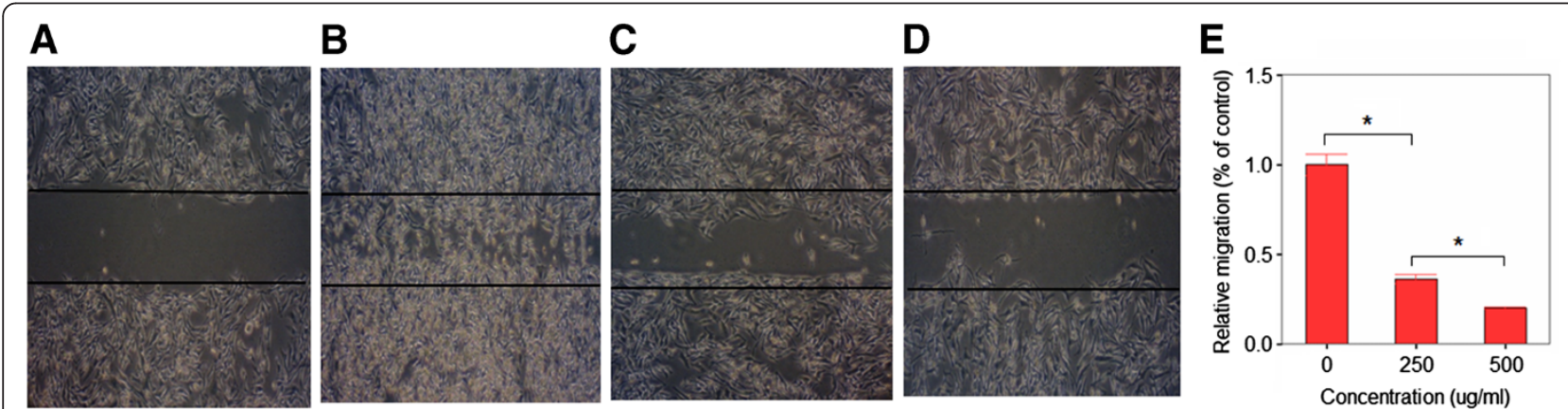

Figure 5 Effect of $P$. indica root crude aqueous extract on migration of HeLa cells as determined by in vitro "scratch" wounjd closure assay. "Scratch" wound closure assay of (A) HeLa cells after 0 hours. (B) HeLa cells after 48 hours incubation with $0 \mu \mathrm{g} / \mathrm{ml} P$. indica root aqueous extract. (C) HeLa cells after 48 hours incubation with $250 \mu \mathrm{g} / \mathrm{ml}$ P. indica root aqueous extract. (D) HeLa cells after 48 hours incubation with $500 \mu \mathrm{g} / \mathrm{ml}$ P. indica root aqueous extract. (E) Statistical analysis of HeLa cells after 48 hours incubation with 0, 250, or $500 \mu \mathrm{g} / \mathrm{ml}$ $P$. indica root aqueous extract. Each experiment was done in triplicate. Error bars show mean \pm SD; bars show means; ${ }^{*} P<0.05$. 

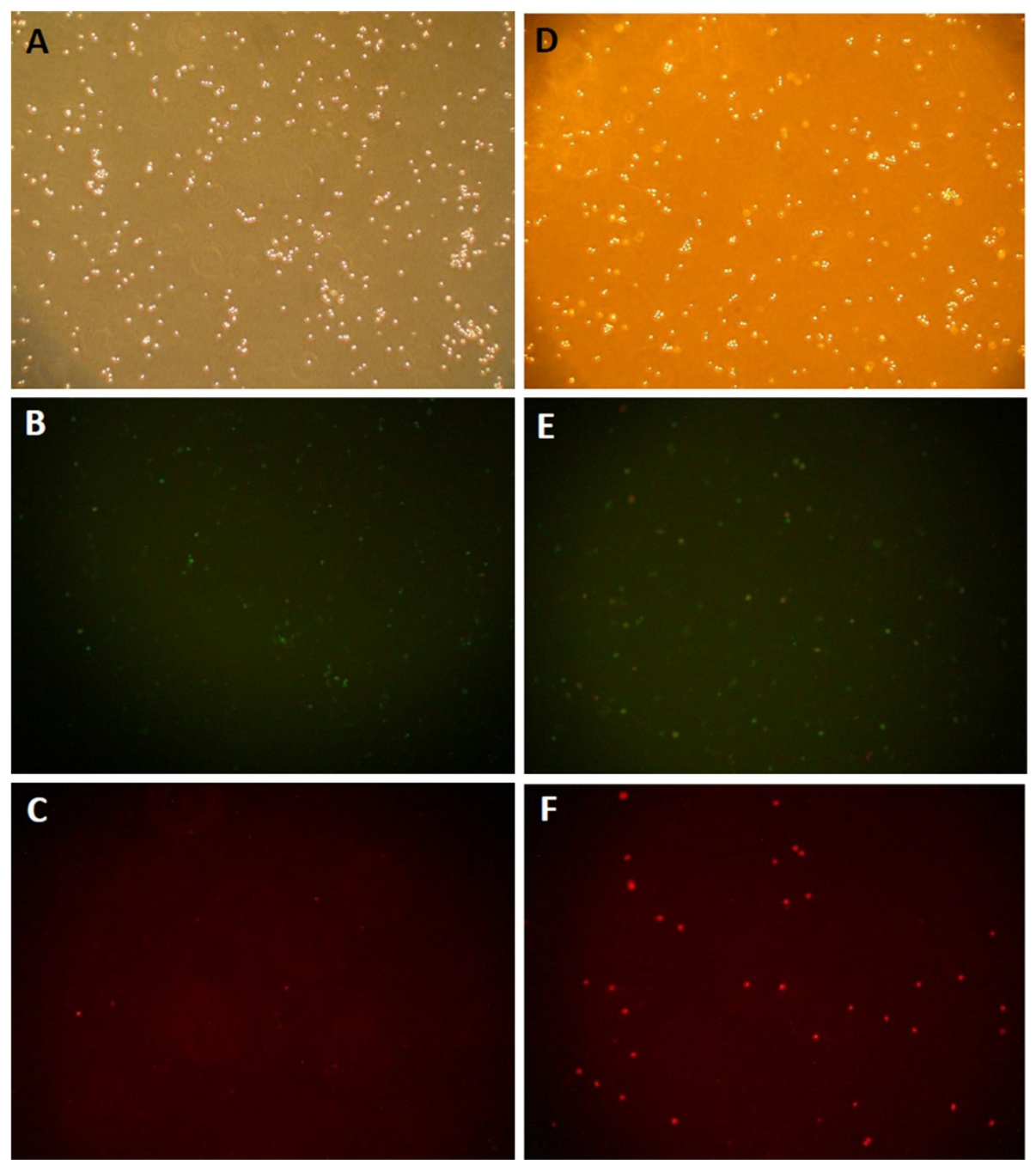

Figure 6 Fluorescence microscopy of HeLa cells treated with crude aqueous root extracts of $P$. indica for 48 hours and double stained with annexin-V-sensitive probe (conjugated to FITC) and propidium iodide. Qualitative labeling of annexin $V$ in the plasma membrane (B and $\mathbf{E}$ ) or cellular uptake of propidium iodide ( $\mathbf{C}$ and $\mathbf{F}$ ) was recorded. Control cells exposed to PBS (A)-(C), and $0.5 \mathrm{mg} / \mathrm{ml}$ of crude aqueous extracts treated cells $(\mathbf{D})-(\mathbf{F})$ were photographed with a microscope $(\times 40)$.

AKT was decreased in HeLa cells treated with $P$. indica root crude aqueous extract.

The medicinal properties of $P$. indica extracts have been studied previously. The methanol fraction of $P$. indica root extract was found to possess antioxidant activity [11]. The methanolic fraction of a chloroform extract of $P$. indica root was found to have anti-inflammatory activity [12]. Beta-sitosterol and stigmasterol isolated from $P$. indica root methanol extract was found to be able to neutralize viper and cobra venom and antagonize cobra venominduced lethality, cardiotoxicity, neurotoxicity, and respiratory changes [13]. In contrast to previous studies, this is the first study to examine the effect of crude aqueous extracts of $P$. indica leaf and root on cancer cells. Tannins, saponins, flavonoids, phenols, and proanthocyanidins were detected in crude aqueous extracts of $P$. indica leaf and root, which showed that $P$. indica has reasonable anticancer potential because total phenolics, flavonoids, and tannins were shown to inhibit ATP-binding cassette transports in cancer cells [21], flavonoid intake was found to associate with a significant reduction in the risk of gastric cancer in women [22], saponins from Radix astragali were found to suppress colon cancer cell carcinogenic activity by reducing vascular endothelial growth factor [23], and proanthocyanidins from grape seeds inhibited pancreatic cancer cell growth and induced apoptosis [24].

Research into the anti-cancer potential of herbal extracts have been growing and expanding $[6,25]$. The compound, n-butylidenephthalide, isolated from the chloroform extract of Angelica siensis was found to upregulate the expression of p21 and p27 and increase apoptosis-associated proteins in DBTRG-05MG and RG2 cells and suppress the 

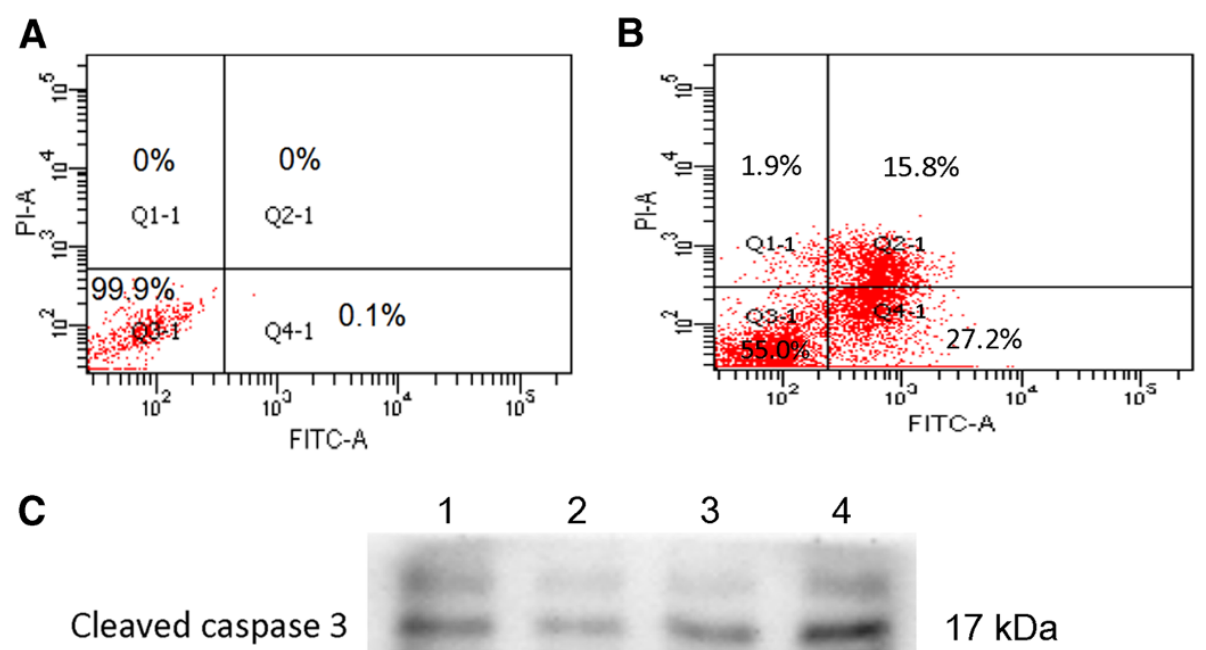

\section{1}

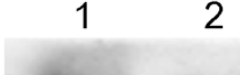

2

3

4

\section{$17 \mathrm{kDa}$}

$\beta$-actin

Figure 7 Flow cytometry analysis of HeLa cells stained with FITC-Annexin V and PI and Western blotting of enhanced expression of cleaved caspase-3. Flow cytometry analysis of FITC-Annexin V and PI stained HeLa cells with untreated HeLa cells (A) and HeLa cells treated with $0.5 \mathrm{mg} / \mathrm{ml}$ P. indica root extract for 48 hours (B). In each scatter plot, upper-left quadrant (Q1-1) shows naked nucleus cell mass, upper-right quadrant (Q2-1) shows necrotic cell mass, lower-left quadrant (Q3-1) shows survival cell mass, and lower-right (Q4-1) shows apoptotic cell mass. In control cells, there were only $0.1 \%$ of apoptotic cells (Figure 7A; Q4-1). After 48 hours of treatment with $0.5 \mathrm{mg} / \mathrm{ml}$ P. indica root aqueous extract, approximately $43 \%$ of cells were detected as undergoing necrosis and apoptosis (Figure 7B; Q2-1+Q4-1). (C) A representative of Western blotting of time-dependent increasing expression of cleaved caspase-3. Cleaved Caspase-3 (Asp175) monoclonal antibody (5A1E; Cell Signaling Technology) used detects levels of the large fragment (17/19 kDa) of activated caspase-3 resulting from cleavage adjacent to Asp175. Lane 1: untreated; lane 2: 1 day of $0.5 \mathrm{mg} / \mathrm{ml}$ extract treatment; lane 3: 2 days of $0.5 \mathrm{mg} / \mathrm{ml}$ extract treatment; lane $4: 3$ days of $0.5 \mathrm{mg} / \mathrm{ml}$ extract treatment. Each experiment was done in triplicate.

growth of subcutaneous rat and human brain tumors [26]. Nexrutine, a Phellodendron amurense bark methanol extract, was found to inhibit prostate cancer cell proliferation through modulation of AKT and cAMP-responsive element binding protein (CREB)-mediated signaling pathway, and that Nexrutine activates cyclin D1, which prevents the progression of prostate cancer [27]. In this study, it was observed that $P$. indica leaf and root aqueous extracts inhibited GBM8401 malignant glioma cells and HeLa cervical carcinoma cell growth, and migration. We found that the crude aqueous extract $P$. indica root suppressed focus formation of GBM8401 and HeLa cells.
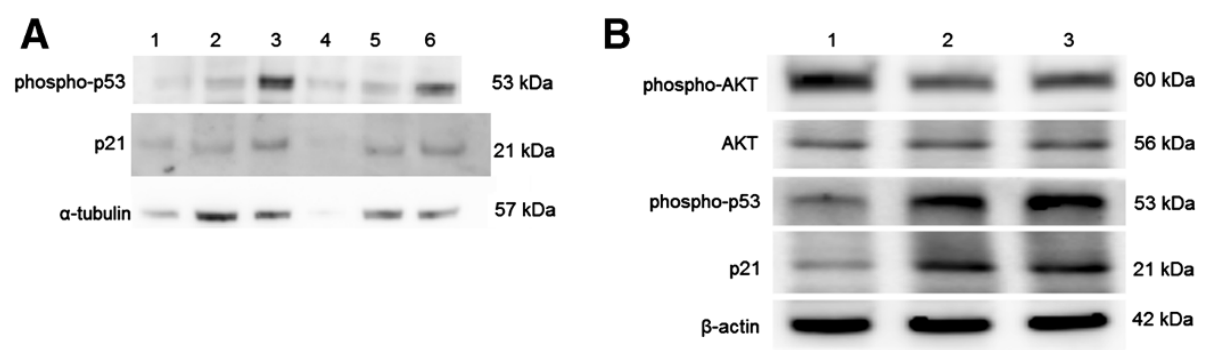

Figure 8 Western blot analysis of phosphorylated-p53 and p21 proteins in cancer cells treated with $P$. indica leaf or root aqueous extract. (A) Western blot of p21 and phosphorylated-p53 proteins of GBM8401 cells after P. indica extract treatment. Lane 1: untreated; lane 2: 3 days of $0.1 \mathrm{mg} / \mathrm{ml}$ P. indica root aqueous extract treatment; lane $3: 3$ days of $1 \mathrm{mg} / \mathrm{ml} P$. indica root aqueous extract treatment; lane $4: 5$ days of $1 \mathrm{mg} / \mathrm{ml}$ $P$. indica root aqueous extract treatment; lane $5: 3$ days of $0.1 \mathrm{mg} / \mathrm{ml} \mathrm{P}$. indica leaf aqueous extract treatment; lane 6: 3 days of $1 \mathrm{mg} / \mathrm{ml} P$. indica leaf aqueous extract treatment. (B) Western blot of p21, phosphorylated-p53, AKT, and phosphorylated-AKT proteins of HeLa cells after $P$. indica extract treatment. Lane 1: untreated; lane 2: 2 days of $0.25 \mathrm{mg} / \mathrm{ml} \mathrm{P}$. indica root aqueous extract treatment; lane $3: 2$ days of $0.5 \mathrm{mg} / \mathrm{ml} P$. indica root aqueous extract treatment. Each experiment was done in triplicate. 
The p53 tumor-suppressor gene does not function properly in most human cancers [28]. In brain cancers, p53 can be inactivated through amino acid-changing mutation in the DNA-binding domain and/or deletion of the $\mathrm{p} 14^{\mathrm{ARF}}$ gene, and in cervical cancers, $\mathrm{p} 53$ is inactivated through viral infection [29,30]. Phosphorylation of p53 by kinases, caused by DNA damage, leads to p53 activation [31]. Phosphorylation of p53 can also occur in response to oxidative stress through the platelet-derived growth factor $\beta$ receptor (PDGF $\beta$ )-mediated ataxia telangiectasia mutated (ATM) kinase activation or direct ATM activation by oxidative stress [32,33]. One of the first consequences of p53 activation is cell cycle arrest through the p53-dependent expression of p $21^{\text {WAF1/CIP1, }}$ an inhibitor of cyclin-dependent kinases (CDKs) [34]. Upregulation of p53 and p21 were found to be induced by lipid peroxidation in previous studies: lipid peroxidation increase was associated with p53 mRNA increase in a rat model [35], lipid peroxidation product from increased ferrous iron level in lysosomal compartment triggered upregulation of p53 [36], lipid peroxidation product sensitizes cells to UV-induced killing by inhibiting nucleotide excision repair and forming a peroxide-DNA adduct at codon 249 of the p53 gene [37], and that hydrogen peroxide-induced lipid peroxide production increased p21 expression [38]. In the present study, it was observed that $P$. indica root crude aqueous extracts caused an increase in membrane lipid oxidation, and induced phosphorylated-p53 and p21expression in GBM8401 and HeLa cells.

The AKT/PKB (protein kinase B) kinases play important roles in signaling pathways that regulate cellular processes controlling cell proliferation, survival, and genome stability [39]. Hyperactivation of the AKT pathway was implicated in many types of human cancer and dominantly inherited cancer syndrome. AKT phosphorylates and inactivates the pro-apoptotic factors BAD and procaspase-9 [39]. In a pro-cell cycle progression mechanism involving $\mathrm{p} 53$, AKT promotes the phosphorylation and translocation of $\mathrm{Mdm} 2$ into the nucleus, where it downregulates p53, which antagonizes p53-mediated cell cycle checkpoints [40]. AKT directly antagonizes the function of the cell cycle inhibitors $\mathrm{p} 21^{\mathrm{WAF} 1}$ and $\mathrm{p} 27^{\mathrm{Kip} 1}$ by phosphorylating a site located near the nuclear localization signal to induce cytoplasmic retention of these cell cycle inhibitors [41]. Some investigations have shown elevated AKT activity to be highly prevalent in high grade, late stage and/or metastatic tumors, and several reports have linked AKT activation with reduced patient survival or tumor radio-resistance [42,43]. In the present study, $P$. indica root crude aqueous extract treatment lowered the expression of activated phosphorylated-AKT, without affecting the expression of non-phosphorylated AKT, and induced the expression of phosphorylated-p53 and p21 in HeLa cells. Therefore, the pro-apoptotic and anti-proliferation properties of the crude aqueous extract of $P$. indica root might be attributed to its induction of phosphorylated-p53 and p21 through the downregulation of activated phosphorylated-AKT, which causes cell cycle arrest and initiation of apoptosis leading to cancer cell death.

The active components in crude aqueous extracts of $P$. indica root may be good candidates for further investigation into the search for effective anti-cancer and synergistic drugs. It is also important to note that aqueous extracts of herbal substance was previously found to be less toxic than ethanol extracts of herbal material; the $\mathrm{LD}_{50}$ of aqueous and ethanol extracts were $12.30 \mathrm{~g} / \mathrm{kg}$ and $6.15 \mathrm{~g} / \mathrm{kg}$, respectively [44]. We found that $P$. indica leaf and root crude aqueous extracts possess pro-oxidant, anti-proliferation, and anti-migration properties in GBM8401 malignant glioma cells and HeLa cervical carcinoma cells, and that $P$. indica root crude aqueous extract inhibited focus formation of these cancer cells. We also found that phosphorylated-p53 and p21 are induced in GBM8401 and HeLa cells after P. indica root crude aqueous extracts treatments. As keenly pointed out by a review, the challenge in CAM is to avoid contaminated products and those that may interact with prescription pharmaceuticals [6]. Further examination into the underlying anti-cancer mechanism and pharmacodynamic and pharmacokinetic interactions with current cancer drugs should be carried out to ensure effective clinical application and usage of $P$. indica leaf or root crude aqueous extract.

\section{Conclusions}

In conclusion, the results of this study suggest that $P$. indica crude aqueous extracts has a promising antiproliferative and anti-migratory effect on GBM8401 malignant glioma cells and HeLa cervical carcinoma cells. In addition, it was found that $P$. indica crude aqueous extracts induced critical tumor suppressor molecules, phosphorylated-p53 and p21, for cell cycle arrest and apoptosis, and downregulated an important survival signaling molecule, phosphorylated-AKT. Further investigations are needed to determine the entire anti-cancer molecular mechanism of $P$. indica aqueous extracts.

\section{Competing interests}

The authors declare that they have no competing interests.

\section{Authors' contributions}

All authors contributed equally in data acquisition and interpretation of the manuscript. All the authors read and approved the final version of the manuscript.

\section{Acknowledgements}

We are grateful to Dr. Tse-Min Lee for helpful comments on determination of lipid peroxidation. The authors are grateful for the experimental assistance 
of the flow cytometry experiment by Joshua Cho and E-Faan Chen and the grow curves, migration assay and part of the Western blotting by Shu-Chuan Tsao. This work is partially supported by "Aim for the Top University Plan" of the National Sun Yat-sen University (to C.L.C), and NSYSU-KMU Joint Research Project \#NSYSUKMU 101-02 (to C.L.C. \& C.N.T.) Taiwan.

\section{Author details}

'Department of Biology, Rensselaer Polytechnic Institute, Troy, NY 12180, USA. ${ }^{2}$ Department of Biological Sciences, National Sun Yat-sen University, Kaohsiung, Taiwan. ${ }^{3}$ Tzu Hui Institute of Technology, Pingtung County, Taiwan. ${ }^{4}$ Graduate Institute of Natural Products, Kaohsiung Medical University, Kaohsiung, Taiwan. ${ }^{5}$ Department of Biotechnology, National Kaohsiung Normal University, Kaohsiung, Taiwan. ${ }^{6}$ Department of Biochemistry, Faculty of Medicine, Kaohsiung Medical University, Kaohsiung, Taiwan.

Received: 29 February 2012 Accepted: 30 November 2012 Published: 26 December 2012

\section{References}

1. Munoz N, Bosch FX, de Sanjose S, Herrero R, Castellsague X, Shah KV, Snijders PJ, Meijer CJ: Epidemiologic classification of human papillomavirus types associated with cervical cancer. N Engl I Med 2003, 348(6):518-527.

2. Wrensch M, Minn Y, Chew T, Bondy M, Berger MS: Epidemiology of primary brain tumors: current concepts and review of the literature. Neuro Oncol 2002, 4(4):278-299.

3. Smith RR, Malmgren RA: Cancer-cell wound seeding in surgery: a review. CA Cancer J Clin 1964, 14:90-103. PASSIM.

4. Timmerman RD, Bizekis CS, Pass HI, Fong Y, Dupuy DE, Dawson LA, Lu D: Local surgical, ablative, and radiation treatment of metastases. CA Cancer J Clin 2009, 59(3):145-170.

5. Van Meir EG, Hadjipanayis CG, Norden AD, Shu HK, Wen PY, Olson JJ: Exciting new advances in neuro-oncology: the avenue to a cure for malignant glioma. CA Cancer J Clin 2010, 60(3):166-193.

6. Cassileth BR: Evaluating complementary and alternative therapies for cancer patients. CA Cancer J Clin 1999, 49(6):362-375.

7. Sparreboom A, Cox MC, Acharya MR, Figg WD: Herbal remedies in the united states: potential adverse interactions with anticancer agents. J Clin Oncol 2004, 22(12):2489-2503.

8. Bardia A, Barton DL, Prokop L, Bauer BA, Moynihan TJ: Efficacy of complementary and alternative medicine therapies in relieving cancer pain: a systematic review. J Clin Oncol 2006, 24(34):5457-5464.

9. Boon H, Stewart M, Kennard MA, Gray R, Sawka C, Brown JB, McWilliam C, Gavin A, Baron RA, Aaron D, et al: Use of complementary/alternative medicine by breast cancer survivors in ontario: prevalence and perceptions. J Clin Oncol 2000, 18(13):2515-2521.

10. McCulloch M, See C, Shu XJ, Broffman M, Kramer A, Fan WY, Gao J, Lieb W, Shieh K, Colford JM Jr: Astragalus-based chinese herbs and platinumbased chemotherapy for advanced non-small-cell lung cancer: metaanalysis of randomized trials. J Clin Oncol 2006, 24(3):419-430.

11. Sen T, Dhara AK, Bhattacharjee S, Pal S, Nag chaudhuri AK: Antioxidant activity of the methanol fraction of pluchea indica root extract. Phytother Res 2002, 16(4):331-335.

12. Sen T, Nag chaudhuri AK: Antiinflammatory evaluation of a pluchea indica root extract. J Ethnopharmacol 1991, 33(1-2):135-141.

13. Gomes A, Saha A, Chatterjee I, Chakravarty AK: Viper and cobra venom neutralization by beta-sitosterol and stigmasterol isolated from the root extract of pluchea indica less. (Asteraceae). Phytomedicine 2007, 14(9):637-643

14. Sen T, Ghosh TK, Chaudhuri AK: Studies on the mechanism of antiinflammatory and anti-ulcer activity of pluchea indica-probable involvement of 5-lipooxygenase pathway. Life Sci 1993, 52(8):737-743.

15. Mohamad S, Zin NM, Wahab HA, Ibrahim P, Sulaiman SF, Zahariluddin AS, Noor SS: Antituberculosis potential of some ethnobotanically selected malaysian plants. J Ethnopharmacol 2011, 133(3):1021-1026.

16. Li XK, Motwani M, Tong W, Bornmann W, Schwartz GK: Huanglian, a chinese herbal extract, inhibits cell growth by suppressing the expression of cyclin B1 and inhibiting CDC2 kinase activity in human cancer cells. Mol Pharmacol 2000, 58(6):1287-1293.
17. Harborne JB: Phytochemical methods: a guide to modern techniques of plant analysis. 3rd edition. London, New York: Chapman and Hall; 1998.

18. Butler $L G$, Price $M L$, Brotherton JE: Vanillin assay for proanthocyanidins (condensed tannins): modification of the solvent for estimation of the degree of polymerization. J Agric Food Chem 1982, 49(3):1169-1174.

19. Janero DR: Malondialdehyde and thiobarbituric acid-reactivity as diagnostic indices of lipid peroxidation and peroxidative tissue injury. Free Radic Biol Med 1990, 9(6):515-540.

20. West KA, Zhang H, Brown MC, Nikolopoulos SN, Riedy MC, Horwitz AF, Turner CE: The LD4 motif of paxillin regulates cell spreading and motility through an interaction with paxillin kinase linker (PKL). J Cell Biol 2001 154(1):161-176.

21. Wink M, Ashour ML, El-Readi MZ: Secondary metabolites from plants inhibiting $A B C$ transporters and reversing resistance of cancer cells and microbes to cytotoxic and antimicrobial agents. Front Microbiol 2012, 3:130.

22. Zamora-Ros R, Agudo A, Lujan-Barroso L, Romieu I, Ferrari P, Knaze V, Bueno-de-Mesquita HB, Leenders M, Travis RC, Navarro C, et al: Dietary flavonoid and lignan intake and gastric adenocarcinoma risk in the european prospective investigation into cancer and nutrition (EPIC) study. Am J Clin Nutr 2012, 96(6):1398-1408.

23. Law PC, Auyeung KK, Chan LY, Ko JK: Astragalus saponins downregulate vascular endothelial growth factor under cobalt chloride-stimulated hypoxia in colon cancer cells. BMC Complement Altern Med 2012, 12:160.

24. Prasad R, Vaid M, Katiyar SK: Grape proanthocyanidin inhibit pancreatic cancer cell growth in vitro and in vivo through induction of apoptosis and by targeting the PI3K/Akt pathway. PLoS One 2012, 7(8):e43064.

25. Ghavami G, Sardari S, Ali Shokrgozar M: Cheminformatics-based selection and synergism of herbal extracts with anticancer agents on drug resistance tumor cells-ACHN and A2780/CP cell lines. Comput Biol Med 2011, 41(8):665-674.

26. Tsai NM, Chen YL, Lee CC, Lin PC, Cheng YL, Chang WL, Lin SZ, Harn HJ: The natural compound $\mathrm{n}$-butylidenephthalide derived from angelica sinensis inhibits malignant brain tumor growth in vitro and in vivo. J Neurochem 2006, 99(4):1251-1262.

27. Kumar AP, Bhaskaran S, Ganapathy M, Crosby K, Davis MD, Kochunov P, Schoolfield J, Yeh IT, Troyer DA, Ghosh R: Akt/cAMP-responsive element binding protein/cyclin D1 network: a novel target for prostate cancer inhibition in transgenic adenocarcinoma of mouse prostate model mediated by nexrutine, a phellodendron amurense bark extract. Clin Cancer Res 2007, 13(9):2784-2794.

28. Vousden $\mathrm{KH}$, Prives $\mathrm{C}$ : Blinded by the light: the growing complexity of p53. Cell 2009, 137(3):413-431.

29. Vogelstein B, Lane D, Levine AJ: Surfing the p53 network. Nature 2000, 408(6810):307-310.

30. Chen TP, Chen CM, Chang HW, Wang JS, Chang WC, Hsu SI, Cho CL: Increased expression of SKP2 and phospho-MAPK/ERK1/2 and decreased expression of p27 during tumor progression of cervical neoplasms. Gynecol Oncol 2007, 104(3):516-523.

31. Brady CA, Jiang D, Mello SS, Johnson TM, Jarvis LA, Kozak MM, Kenzelmann Broz D, Basak S, Park EJ, McLaughlin ME, et al: Distinct p53 transcriptional programs dictate acute DNA-damage responses and tumor suppression. Cell 2011, 145(4):571-583.

32. Chen K, Albano A, Ho A, Keaney JF Jr: Activation of p53 by oxidative stress involves platelet-derived growth factor-beta receptor-mediated ataxia telangiectasia mutated (ATM) kinase activation. J Biol Chem 2003, 278 (41):39527-39533.

33. Guo Z, Kozlov S, Lavin MF, Person MD, Paull TT: ATM activation by oxidative stress. Science 2010, 330(6003):517-521.

34. Seoane J, Le HV, Massague J: Myc suppression of the p21(Cip1) Cdk inhibitor influences the outcome of the $\mathrm{p} 53$ response to DNA damage. Nature 2002, 419(6908):729-734.

35. Koz ST, Etem EO, Baydas G, Yuce H, Ozercan HI, Kuloglu T, Koz S, Etem A, Demir N: Effects of resveratrol on blood homocysteine level, on homocysteine induced oxidative stress, apoptosis and cognitive dysfunctions in rats. Brain Res 2012, 1484:29-38.

36. Bresgen N, Jaksch H, Lacher H, Ohlenschlager I, Uchida K, Eckl PM: Ironmediated oxidative stress plays an essential role in ferritin-induced cell death. Free Radic Biol Med 2010, 48(10):1347-1357.

37. Feng Z, Hu W, Tang MS: Trans-4-hydroxy-2-nonenal inhibits nucleotide excision repair in human cells: a possible mechanism for lipid 
peroxidation-induced carcinogenesis. Proc Natl Acad Sci USA 2004, 101(23):8598-8602.

38. Lee $\mathrm{YJ}$, Lee $\mathrm{JH}, \mathrm{Han} \mathrm{HJ}$ : Extracellular adenosine triphosphate protects oxidative stress-induced increase of p21(WAF1/Cip1) and p27(Kip1) expression in primary cultured renal proximal tubule cells: role of PI3K and Akt signaling. J Cell Physiol 2006, 209(3):802-810.

39. Bellacosa A, Kumar CC, Di Cristofano A, Testa JR: Activation of AKT kinases in cancer: implications for therapeutic targeting. Adv Cancer Res 2005, 94:29-86.

40. Zhou BP, Hung MC: Novel targets of Akt, p21(cipl/WAF1), and MDM2. Semin Oncol 2002, 29(3 Suppl 11):62-70.

41. Testa JR, Bellacosa A: AKT plays a central role in tumorigenesis. Proc Nat Acad Sci USA 2001, 98(20):10983-10985.

42. Tsao AS, McDonnell T, Lam S, Putnam JB, Bekele N, Hong WK, Kurie JM: Increased phospho-AKT (Ser(473)) expression in bronchial dysplasia: implications for lung cancer prevention studies. Cancer Epidemiol Biomarkers Prev 2003, 12(7):660-664

43. Balsara BR, Pei J, Mitsuuchi Y, Page R, Klein-Szanto A, Wang H, Unger M, Testa JR: Frequent activation of AKT in non-small cell lung carcinomas and preneoplastic bronchial lesions. Carcinogenesis 2004, 25(11):2053-2059.

44. Frida L, Rakotonirina S, Rakotonirina A, Savineau JP: In vivo and in vitro effects of bidens pilosa L. (Asteraceae) leaf aqueous and ethanol extracts on primed-oestrogenized rat uterine muscle. Afr J Tradit Complement Altern Med 2007, 5(1):79-91.

doi:10.1186/1472-6882-12-265

Cite this article as: Cho et al:: Crude aqueous extracts of Pluchea indica (L.) Less. inhibit proliferation and migration of cancer cells through induction of p53-dependent cell death. BMC Complementary and Alternative Medicine 2012 12:265.

\section{Submit your next manuscript to BioMed Central and take full advantage of:}

- Convenient online submission

- Thorough peer review

- No space constraints or color figure charges

- Immediate publication on acceptance

- Inclusion in PubMed, CAS, Scopus and Google Scholar

- Research which is freely available for redistribution 